\title{
Towards a Multi-faceted Vadose Zone Assessment Protocol: Cemetery \\ Guidelines and Application to a Burial Site located near a Seasonal Wetland (Pretoria, South Africa)
}

Matthys A. DIPPENAAR

Engineering Geology and Hydrogeology, Department of Geology, University of Pretoria, Private Bag X20, Hatfield, 0028, Pretoria, South Africa

+27(0)124203117

madip@up.ac.za / madippenaar@gmail.com / www.up.ac.za/geology

Abstract: Cemeteries are generally considered low-risk landfills and are, therefore, not adequately governed in terms of minimum requirements for engineering geological and hydrogeological investigations. With the decay of human bodies, bulk of the contaminant load typically is present within one year of burial and decreases over time. Further controls include adsorption of pathogens and particulates to soil in the vadose zone and eventual breakdown in changing aerobic and anaerobic subsurface environments. A case study is presented where a cemetery has been active for decades and contains in excess of 18000 human bodies. With recent expansion, water seepage was identified into newly excavated burial pits and all further development has ceased. Trial pitting and detailed soil profile descriptions are used to infer hydrological interaction at the site and to address possible contamination pathways. Future work is recommended with respect to water quality, although valuable insight is provided to the consequences of improper ground investigation prior to development. Final comments are made regarding provisional guidelines in the 
forms of a Cost-Effort-Risk Screen and a multi-faceted Vadose Zone Assessment Protocol.

Keywords: cemetery; vadose zone; burial; ground investigation; interment;

\section{Introduction}

Burial or interment is a basic social need and, to many extents, a moral practice depending on culture. However, siting of cemeteries and grave sites lose focus of the environmental implications at the expense of these cultural needs. Although necessary and an important aspect, the issue is not interment per se, but rather the oversight of scientifically sound investigation techniques of this activity which does influence the environment. Issues are generally fourfold, in the opinion of the author, and include (1) social matters, which fall outside of the scientific regime, and include communities requiring specific placement of burial sites (e.g. on hills or in floodplains) and the growth of these sites; (2) environmental or sanitary issues such as resulting water contamination; (3) engineering issues which contribute to the social and environmental aspects, including, for instance, stability of the grave and ease of excavation of the site materials; and (4) the lack of an enforced document collating principles and approaches employed in South Africa.

The aim of this study is to address shortcomings of existing investigation techniques at the hand of a cemetery influenced by seasonal wetland conditions in South Africa. Additionally, provisional guidelines are outlined, which are 
presently being formalised as part of a South African Water Research Commission funded project.

\section{Literature}

\section{1. $\quad$ Risk associated with cemeteries}

Cemeteries do pose risk. Decay of organic material will inevitably result in some form of contamination of the subsurface; whether this reaches receptors (through for instance groundwater, surface water or the biosphere) is subject to the quality of the land use investigation, the ability of the vadose zone to protect groundwater and the practices employed in interments.

According to the Department of Water Affairs (DWA 2010), the risk of pollution to water resources posed by cemeteries is acceptable and mostly negligible. Reasons stipulated include the slow process associated with the decay of human bodies and the short lifespan of bacteria outside of the human body, reticulated water supply which ensures good quality drinking water, more significant contamination emanating from other sources (e.g. waste disposal sites and sewage), and the fact that other uses - such as irrigation - exist for slightly contaminated water.

According to Section 21 of the Environmental Conservation Act (DEAT 1989), the “... change of land use to that of a cemetery is subject to a mandatory Environmental Impact Assessment (EIA)". Poorly sited cemeteries can pose a 
pollution threat to the environment, including short-term impacts such as noise, flies and air pollution, as well as long-term impacts such as pollution to the water regime. Decomposition of buried human corpses results in groundwater contamination due to, for instance, residues or particulates and pathogens that are generated during the decomposition process (Fisher \& Croucamp 1993).

Vulnerability is accentuated in areas with high rainfall, shallow water tables, fractured rocks and any other high permeability areas. The risk of water contamination is, furthermore, increased where burial is near the water table or next to groundwater abstraction points as this reduces the time needed for mobile waste production to degrade completely and for the geological subsurface material to purify the potential pathogens. Additionally, contamination can be increased where corpses are buried in direct contact with the groundwater, causing reduction in the time taken for mobile degradation to reach the subsurface, or with an increase in number of burials (Engelbrecht 2000).

For this reason, some sources (e.g. NIEA 2012) stipulate criteria for safe siting of burial sites with the purpose of protecting water resources. Intrusive investigation should be at least $2.8 \mathrm{~m}$ deep to account for a $1.8 \mathrm{~m}$ deep grave and to prove $1.0 \mathrm{~m}$ of additional subsoil below the base of the burial pit. At least $1 \mathrm{~m}$ of soil should cover the coffin. The grave pit should be at least $10 \mathrm{~m}$ from any field drain, 50 m from any watercourse, spring, well or borehole (although WHO 1996, EA 2004 and Young 2002 stipulate $30 \mathrm{~m}$ ), and at least $250 \mathrm{~m}$ from any drinking water source. 
The influence of infiltrating water is explained through Fig. 1. Backfill material in graves may be less compacted than the in-situ material and may, therefore, act as preferential pathways. Resulting from this, the graves may be near water saturation, resulting in anaerobic conditions for the breakdown of the organic matter. Interaction and interflow may occur between proximate graves, and/ or contaminated water may enter the vadose zone below the grave bottom if the water table is sufficiently deep. Natural attenuation of contaminants may occur in the vadose zone due to possible aerobic conditions in this aerated zone. Shallower groundwater should be more vulnerable to contamination due to the thinner vadose zone decreasing natural attenuation and possible mounding of the water table, which can even result in a periodical contact between the grave bottom and the groundwater table.

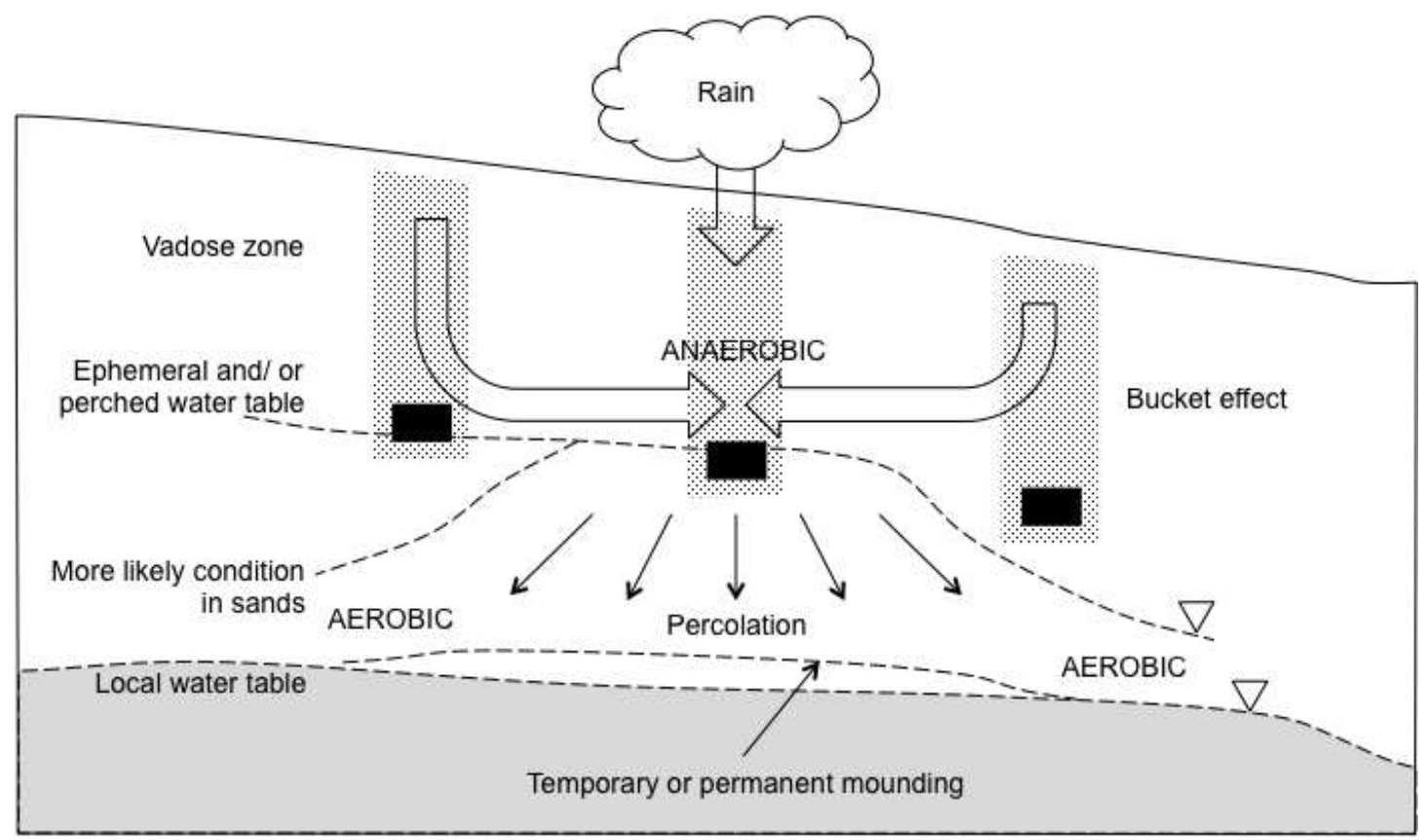

Figure 1. Interaction between graves and the subsurface hydrology (adapted from Dent and Knight 1998). 
Risk is, furthermore, exacerbated by the proximity of surface water drainage features and, notably, streams in direct interaction with the regional groundwater (Fig. 2a) whereas losing streams (Fig. 2b) are possibly more protected as the groundwater flow may be in an opposite direction at a local scale. Deep groundwater systems (Fig. 2c) are likely most protected due to the thick vadose zone enhancing natural attenuation.

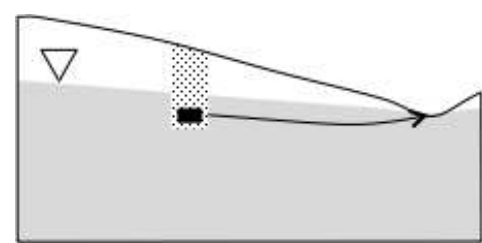

(a)

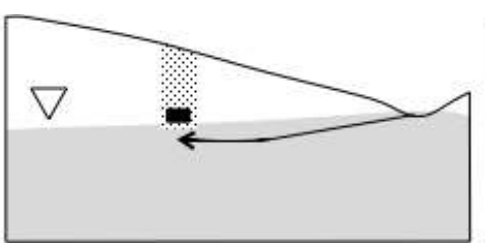

(b)



(c)

Figure 2. Hypothetical interactions between graves sites and (a) a gaining stream at risk from contamination from gravesites, (b) losing stream possibly more protected and (c) deep groundwater table with possible contamination (arrows indicate likely flow directions).

Sorption and intense chemical and biochemical degradation predominates in the soil zone in which the grave is located. The vadose zone is governed by continued sorption with reduced chemical and biochemical degradation. The phreatic zone is characterised by distinct dispersion and dilution of contaminants and processes are a function of the aquifer material and groundwater chemistry (EA 2004). Adsorption results in attenuation and capture of particulates, whereas filtration (due to water flow) results in, for instance, straining or retention due to changing pore geometry (Young et al. 2002). 
A lean $70 \mathrm{~kg}$ adult male human body is composed of approximately $16000 \mathrm{~g} \mathrm{C}, 1$ 800 g N, 1100 g Ca, 500 g P, 140 g S, 140 g K, 100 g Na, 95 g Cl, 19 g Mg, 4.2 g Fe and $70-74 \%$ water by weight. Females are generally two thirds to three quarters of this and other elements occur in millimole and micromole amounts (Dent and Knight 1998; Forbes 1987). A human corpse decays in 10 - 12 years and comprises matter of which $60 \%$ is readily degradable, $15 \%$ moderately degradable, $20 \%$ slowly degradable and $5 \%$ inert. Half the pollutant load can leach within the first year with less than $0.1 \%$ of the contaminant load remaining after 10 years. Influences on decay include climate and soil lithology where warmer temperatures and well-drained soils will accelerate decomposition, as well as burial practice, which includes the depth of burial and coffin construction (EA 2004; Young et al. 2002).

The WHO (1996) addresses factors affecting the survival of bacteria and viruses from burial sites. Increasing the temperature between $5^{\circ} \mathrm{C}$ and $30^{\circ} \mathrm{C}$, microorganisms die off at a rapidly increasing rate. Optimal $\mathrm{pH}$ is around 6 - 7 and beyond either extreme their possible survival decreases significantly. Soil $\mathrm{pH}$, cations and soil texture all contribute to possible water retention and adsorption of viruses to soils. Importantly, bulk of the pathogens is adsorbed to the soil, but increasing water velocity decreases this adsorption.

All in all, even though the risk posed by cemeteries is possibly lower than other sources of contamination, a risk still does exist. This risk is increased by the typical location of these sites within developed residential areas and peri-urban nodes where groundwater and surface water are often used for domestic 
purposes. Proper site investigation will result in proper siting and proper management of burial sites, thereby lowering the risk further.

\subsection{Site investigation for cemeteries}

Although considered low risk, the Department of Water Affairs (DWA) acknowledges the potential risk through certain guidelines. Cemeteries implemented after 1998 constitute a water use according to section 21(g) of the National Water Act (NWA in DWA 1998) and new cemeteries following the implementation of this act needs to be authorised. Section 21(g) states that licensing is required when "... disposing of waste in a manner which may detrimentally impact on a water resource." They continue to state that poor siting of cemeteries leading to increased risk is due to poor land use planning from the local government and detection of pollution due to cemeteries will be enforced according to the act. Finally, local authorities manage the implementation, legislation and land use planning and should govern the location according to the NWA that cemeteries should not be located:

- Within the 1 in 50 year floodline of a river

- Near water bodies such as wetlands, pans, vleis, estuaries and floodplains

- Near unstable areas such as fault zones and karst areas

- Near ecologically sensitive areas

- In areas with shallow gradients or shallow or emergent groundwater

- In areas with steep gradients, shallow bedrock or areas prone to slope failure

- In areas of groundwater recharge due to topography or soil permeability 
- Overlying or adjacent to (potentially) important water supply aquifers.

Hall and Hanbury (1990) recommend a six-fold investigation based on physical aspects (excavatability, stability of sidewalls and workability through replacement of removed soil back into the grave) and sanitary aspects (position of the water table, subsoil permeability and the presence of attenuation or aeration zones, and drainage as the risk of water draining through the backfill material into the grave) as shown in Table 1. 
Table 1. Physical and sanitary aspects for cemetery site investigation (adapted from Hall and Hanbury 1990).

\begin{tabular}{|c|c|c|c|}
\hline EXCAVATABILITY & \multicolumn{2}{|l|}{ Assessment } & Rating Score \\
\hline Easy spade & \multicolumn{2}{|c|}{ Geological pick pushed in $50 \mathrm{~mm}$ with ease } & 15 \\
\hline Pick and spade & \multicolumn{2}{|c|}{ Geological pick causes slight indentation } & 10 \\
\hline Machine & \multicolumn{2}{|c|}{ Firm blows with pick cause $1-3 \mathrm{~mm}$ indentations } & 5 \\
\hline Blasting & \multicolumn{2}{|l|}{ Backactor refusal } & 0 \\
\hline STABILITY & \multicolumn{2}{|l|}{ Assessment } & Rating Score \\
\hline Stable & \multicolumn{2}{|c|}{ Little overbreak with safe excavation profiling } & 20 \\
\hline Overbreak & \multicolumn{2}{|c|}{ Overbreak between 1.3 and $1.8 \mathrm{~m}$} & 15 \\
\hline Slightly unstable & \multicolumn{2}{|c|}{ Minor falls of material } & 8 \\
\hline Unstable & \multicolumn{2}{|c|}{ Collapse of excavation likely } & 1 \\
\hline WORKABILITY & Unified & MOD AASHTO & Rating Score \\
\hline Excellent to good & GW. SW, GP & $>1800 \mathrm{~kg} / \mathrm{m}^{3}$ & 10 \\
\hline Fair & SP, SM & $<1800 \mathrm{~kg} / \mathrm{m}^{3}$ & 5 \\
\hline Poor & $\mathrm{OL}, \mathrm{CL}, \mathrm{NL}$ & $<1700 \mathrm{~kg} / \mathrm{m}^{3}$ & 2 \\
\hline Very poor & OH. CH, MH & $<1500 \mathrm{~kg} / \mathrm{m}^{3}$ & 0 \\
\hline WATER TABLE & \multicolumn{2}{|c|}{ Water Table Depth (m) } & Rating Score \\
\hline Deep water table & \multicolumn{2}{|l|}{$>8$} & 25 \\
\hline Intermediate water table & \multicolumn{2}{|l|}{$4-8$} & 5 \\
\hline Possible perched water table & \multicolumn{2}{|l|}{$0-4$} & 5 \\
\hline Waterlogged soil & \multicolumn{2}{|l|}{$0-4$} & Fail \\
\hline SUBSOIL PERMEABILITY & Percolation Rate & Approx. Permeability & Rating Score \\
\hline Impermeable & Not measurable & $<10^{-7} \mathrm{~m} / \mathrm{s}$ & 15 \\
\hline Relatively impermeable & $10-15 \mathrm{~mm} / \mathrm{h}$ & $10^{-6}-10^{-7} \mathrm{~m} / \mathrm{s}$ & 20 \\
\hline Relatively permeable & $15-50 \mathrm{~mm} / \mathrm{h}$ & $10^{-5}-10^{-6} \mathrm{~m} / \mathrm{s}$ & 10 \\
\hline
\end{tabular}




\begin{tabular}{|l|l|l|l|}
\hline Permeable & $50-1000 \mathrm{~mm} / \mathrm{h}$ & $<10^{-5} \mathrm{~m} / \mathrm{s}$ & 0 \\
\hline BACKFILL PERMEABILITY & Unified Class & Rating Score \\
\hline $\begin{array}{l}\text { Impermeable } \\
\text { Relatively impermeable }\end{array}$ & OH, CL, CH, SC, MH & 10 \\
Relatively permeable & GP, SP, GW & 7 \\
Very permeable & SW, SP & 0 \\
\hline FINAL RANKING & Suitability & \\
\hline$>90$ & Very good & \\
$75-90$ & Satisfactory & \\
$60-75$ & Poor - precautions required & \\
$<60$ & Unacceptable & \\
\hline
\end{tabular}

Fisher (1992) recommends investigation of geological factors influencing soil conditions, underlying rock, groundwater conditions and surface water. Soil conditions include soil type, structure, density, permeability and moisture content whereas underlying rock comprise bedrock, pedogenic material, joint and discontinuity frequency, joint condition, joint fill material and degree of weathering. Groundwater conditions relate to the depth of the permanent water table, frequency of perched water tables, prevailing hydraulic gradient, as well as the relationship between topography and groundwater table. Surface water occurring in drainage features refers to perennial or non-perennial streams, as well as the frequency of flow of the latter, stream order, storage dams, topographical and climatic influences, slope shape and gradient, and the incised nature of the landscape. 
Following on the abovementioned, Fisher (1994) also recommends the following requirements for a site to serve as a cemetery:

- The surface gradient should be between $2^{\circ}$ and $6^{\circ}$ (up to $9^{\circ}$ in extreme cases) to ensure adequate drainage of the site, to minimise erosion and to promote mobility on site.

- The soil profile depth should be at least $1.80 \mathrm{~m}$ for ease of excavation.

- The soil consistency should be such that it ensures the stability of the grave walls for a few days.

- The underlying site soils should have a low permeability $\left(10^{-5}\right.$ to $10^{-6}$ $\mathrm{cm} / \mathrm{s}$ ) to prevent groundwater contamination.

- The site should be located at least $100 \mathrm{~m}$ from the 50-year flood line.

- The groundwater depth should exceed $4 \mathrm{~m}$.

- A buffer zone of at least $2.5 \mathrm{~m}$ should be present between the bottom of the grave and the top of the groundwater table.

- No drainage channels should intersect the proposed cemetery area.

- The site should not be underlain by dolomitic material.

- No borehole drinking water should be located closer than $500 \mathrm{~m}$ of the proposed cemetery.

- The cemetery should be large enough for future expansions at an estimated 3000 graves per hectare.

Croucamp and Richards (2002) recommend ten selection criteria based on engineering and hydrological conditions. Based on all the following factors, a cemetery can be considered suitable or unsuitable: 
- Soil excavatability, pertaining to the ease of grave excavation without any mechanical aid, to a minimum depth of $1.80 \mathrm{~m}$, is addressed according to soil consistency. Very loose to loose (very soft to soft) material is readily excavated by means of a spade and will be suitable, provided that grave stability is not a problem. Medium dense (or firm) material requires picks and spades and is considered ideal. Exceeding this will require back actors, jack hammers or blasting which may not always be affordable and the shallow bedrock leading to harder excavation conditions may not be suitable for grave sites.

- Soil permeability relates to the rate of fluid movement through the soil and must be between $1 \times 10^{-7} \mathrm{~cm} / \mathrm{s}$ and $5 \times 10^{-5} \mathrm{~cm} / \mathrm{s}$. Where the cemeteries are located further from water sources than recommended, the upper limit can be extended to $1 \times 10^{-4} \mathrm{~cm} / \mathrm{s}$.

- The position with respect to domestic water sources depends on the soil permeability range and the maximum survival times of several bacteria and viruses.

- The position with respect to drainage features (including lakes, dams, rivers, streams and gully heads) is important to ensure that these features are not affected in any way by pollutants from the cemetery sites.

- Site drainage should ensure minimal ingress of surface water into the graves and storm water run-off should be implemented to ensure this.

- Site topography should ideally have a gradient between $2^{\circ}$ and $6^{\circ}$ with a maximum gradient of $9^{\circ}$ being considered acceptable. 
- The basal buffer zone refers to the vertical soil succession between the base of the deepest grave and the water table, forming a barrier between the source of pollution (the grave) and the groundwater.

- Grave stability is required to ensure competency in the excavated graves.

- Soil workability entails the ease of manipulation of soil from and into the grave.

- Cemetery size, finally, is often limited by the lack of suitable conditions due to, for instance, dense drainage networks and the required capacity for the intended community.

For all practical purposes, investigations are twofold and include (1) geotechnical or engineering geological aspects regarding stability and workability, and (2) environmental, hydrological or sanitary aspects regarding potential contamination of proximate water sources.

\section{Materials and Methods}

\subsection{Study area}

The Temba Cemetery is shown in Fig. 3 and is situated in Temba, approximately $40 \mathrm{~km}$ north of Pretoria in the City of Tshwane Municipality (Gauteng Province, South Africa). As a peri-urban node developed in the mid to late 1900s, the cemetery presently has 13673 adult graves and 4695 child graves amounting to a total of 18368 . Apart from fairly high density peri-urban development around 
the cemetery, the site itself is covered by grass veldt which has possibly been somewhat disturbed through historical agricultural practices.

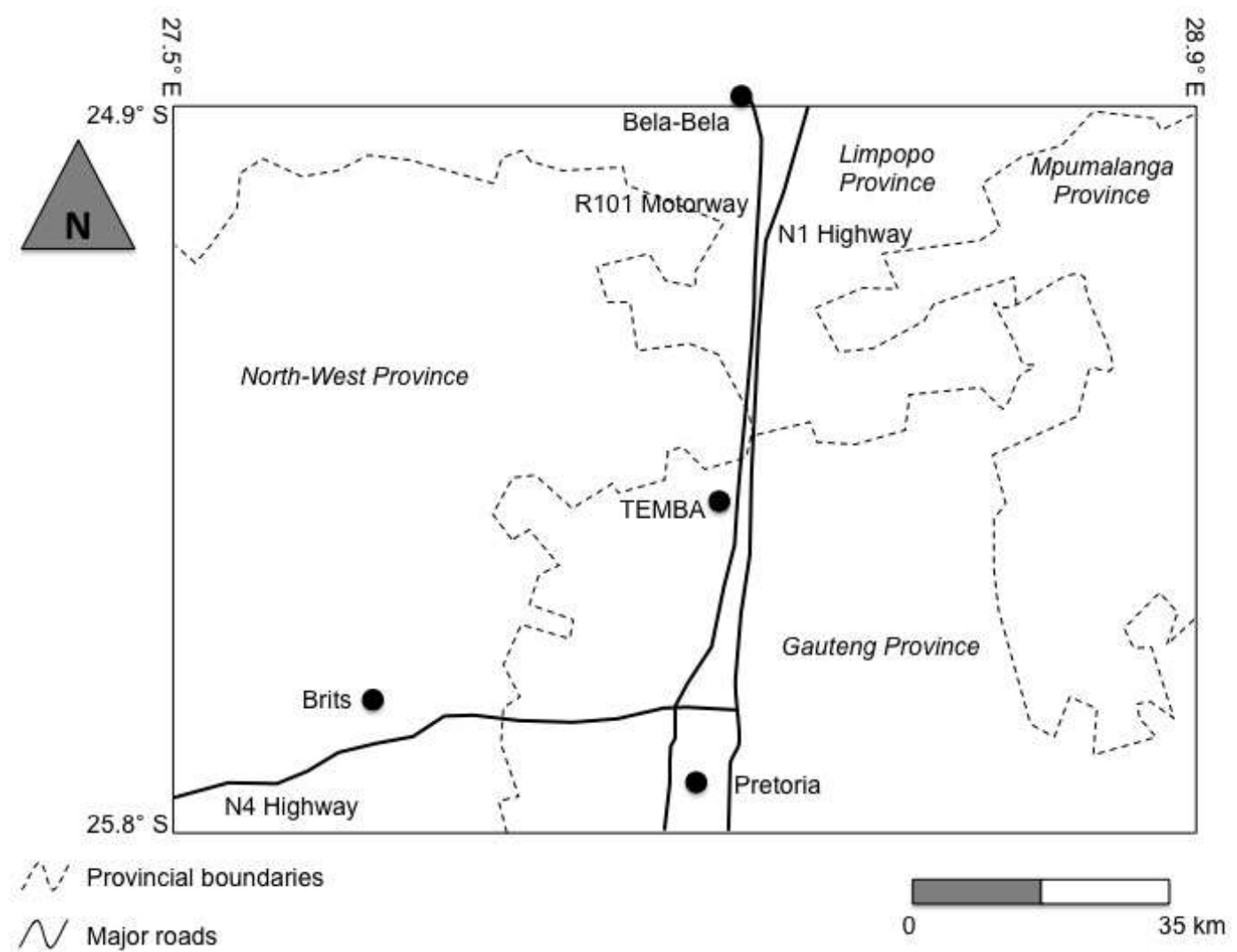

Figure $3 . \quad$ Locality of the Temba Cemetery.

Interments have ceased since the detection of water seepage into newly excavated graves. Expansion of the cemetery was towards a wetland feature to the southwest until detection of water seepage into new burial pits (Fig. 4). 


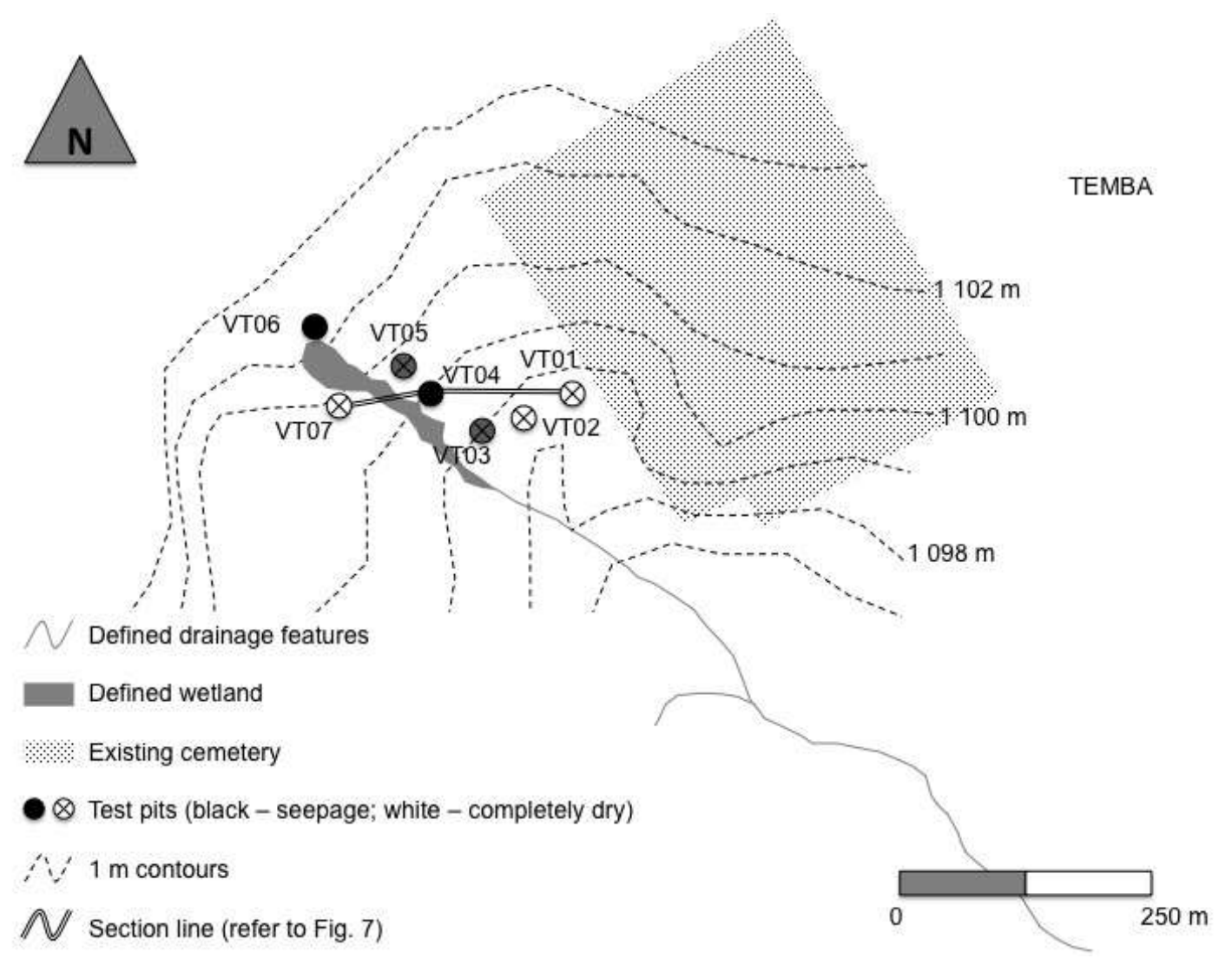

Figure 4. The existing Temba Cemetery (yellow shading), wetland, surface drainage and excavated test pits depicted on one-meter surface contours.

\subsection{Topography and hydrology}

Temba Cemetery is situated in the A23F quaternary catchment of the Crocodile/ Marico (West) Water Management Area (WMA3). Surface drainage is towards the southwest into the Apies River, located approximately $2.5 \mathrm{~km}$ away.

The site itself slopes fairly shallowly at an approximate gradient of 1:60. The surface gradient is roughly to the east in the western portions of the site and to the south in the northern portions of the site. A wetland forms on the slope, eventually forming a small non-perennial stream draining towards the southwest. The wetland is believed to be seasonally waterlogged. 
According to a series of Hydrogeological Maps of South Africa (published jointly by the DWA and the Water Research Commission in 1996), the electrical conductivity of groundwater is between 70 and $300 \mathrm{mS} / \mathrm{m}$, groundwater recharge is 50 - $110 \mathrm{~mm}$ per annum, groundwater depth vary between 20 and $30 \mathrm{~m}$ (standard deviation $25 \mathrm{~m}$ ) and groundwater is of the $(\mathrm{Ca}, \mathrm{Mg})\left(\mathrm{HCO}_{3}\right)_{2}$-type. Nitrate concentrations are noted as exceeding $10 \mathrm{mg} / \mathrm{l}$ in more than $20 \%$ of historical samples analysed.

\subsection{Geology}

The extensive deposits of the Karoo Supergroup generally vary between arenaceous to argillaceous sedimentary rocks with localised coal beds. Additional to this are also the intrusive dolerite dykes and extrusive mafic to ultramafic lavas marking the later stages of the stratigraphy, although these are not generally identified in the Pretoria region. The combined Karoo Supergroup ranges in age between 290 and $190 \mathrm{Ma}$ and - in the area under consideration are characterised by the Ecca Group deposited after southward polar migration and the subsequent warmer climate within the Springbok Flats Basin. Proximate to Pretoria, the Springbok Flats Basin of the Karoo Supergroup overlies the Dwyka Group with the Hammanskraal Formation being the most common in the area. At the site itself, bedrock comprises intercalated shale to siltstone or fine sandstone with eventual pale brown to orange brown fine sandstone at depth (Brink 1983; Johnson et al. 2009). 


\subsection{Investigation techniques}

The investigation comprised excavation of seven test pits by means of a backactor (backhoe). Excavation was ceased on refusal or end of reach, ensuring to reach a maximum possible depth. Test pits were spaced to address geological and pedological variation along the drainage, as well as perpendicular thereto.

Representative samples were submitted for grading and hydrometer analyses, as well as to determine the Atterberg limits.

\section{Findings}

\subsection{Geological and pedological characterisation}

The land cover subdivides the site into a number of characteristic zones (Fig. 5). From the slopes at the existing cemetery, the succession of materials change to distinct duplex soils (enrichment in clay minerals downslope due to translocation of clay particles by moving water) with clayey surface horizons (grass covered), followed by clayey soils overlain by sandy topsoil where precipitation of salts on surface is indicative of high evaporation (barren land). The wetland itself is also clayey and waterlogged and characterised by reeds and grasses adapted to waterlogged conditions. 


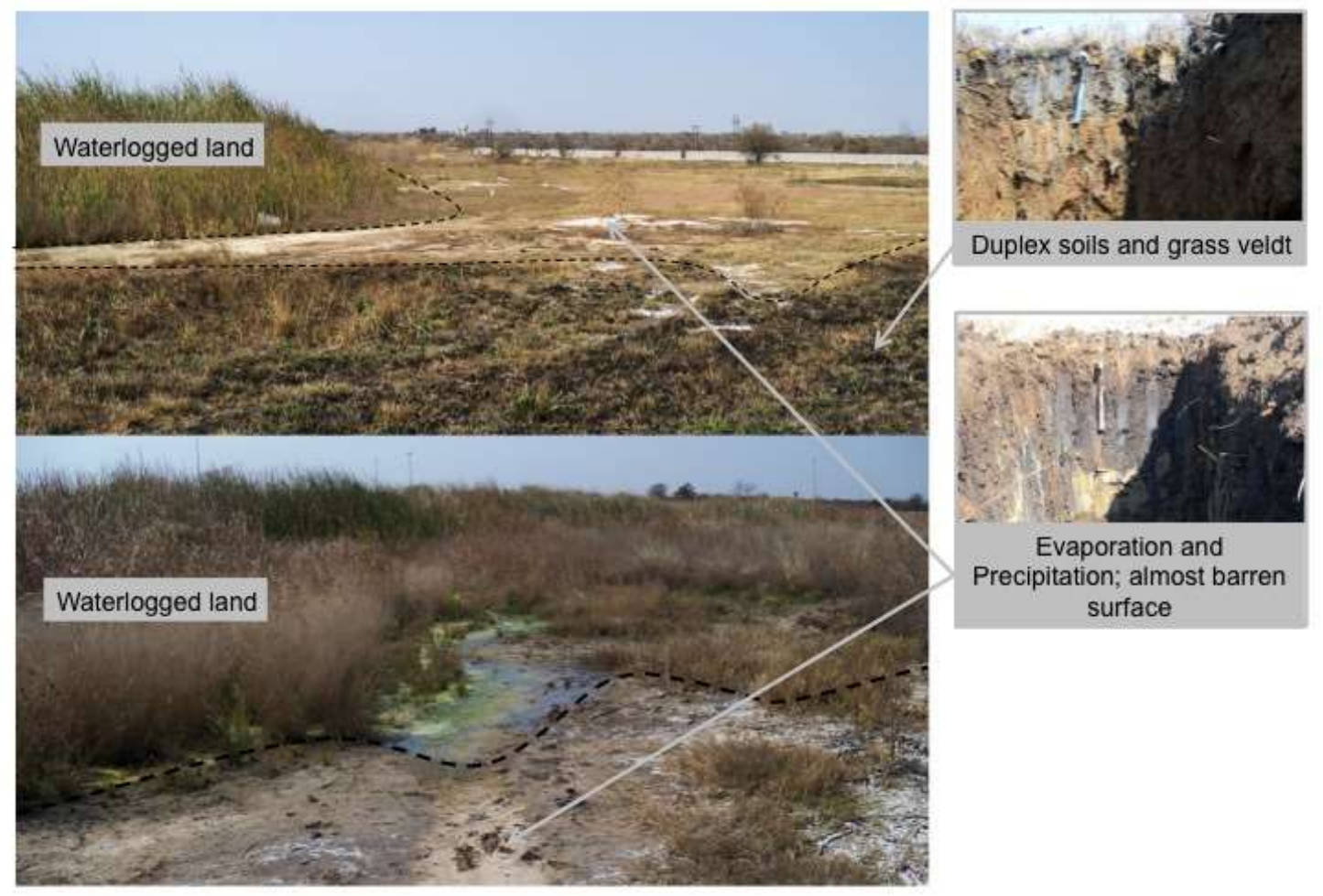

Figure 5. Characteristic changes from flat upper slopes through clayey duplex soils, evaporation and precipitation zones with thin sandy topsoil, to waterlogged land.

The test pit positions are shown in the site plan (Fig. 4) and are summarised in Fig. 6. Photographs of selected test pits prior to significant water influx (i.e. immediately following excavation) are also shown. Typical material descriptions are as follows:

- Colluvium - moist to wet, dark brown or grey, soft to firm, shattered and slickensided, silty clay near drainage feature, becoming slightly moist, dark reddish brown (streaked grey speckled olive), dense, shattered, clayey silty sand or firm, pinholed, sandy clay or clayey silt with increasing distance 
- Residuum - moist, orange brown blotched olive or (light) olive blotched orange and grey, very soft, slightly slickensided to shattered, silty clay; occasionally with calcrete nodules

- Bedrock - moist, grey to olive grey stained orange and white, soft, laminated (in places), clay-silt to sandy in places; completely weathered shale, siltsone and sandstone becoming dull pale brown stained white, orange and black, laminated and jointed, intercalated fine-grained shale, siltstone and sandstone.
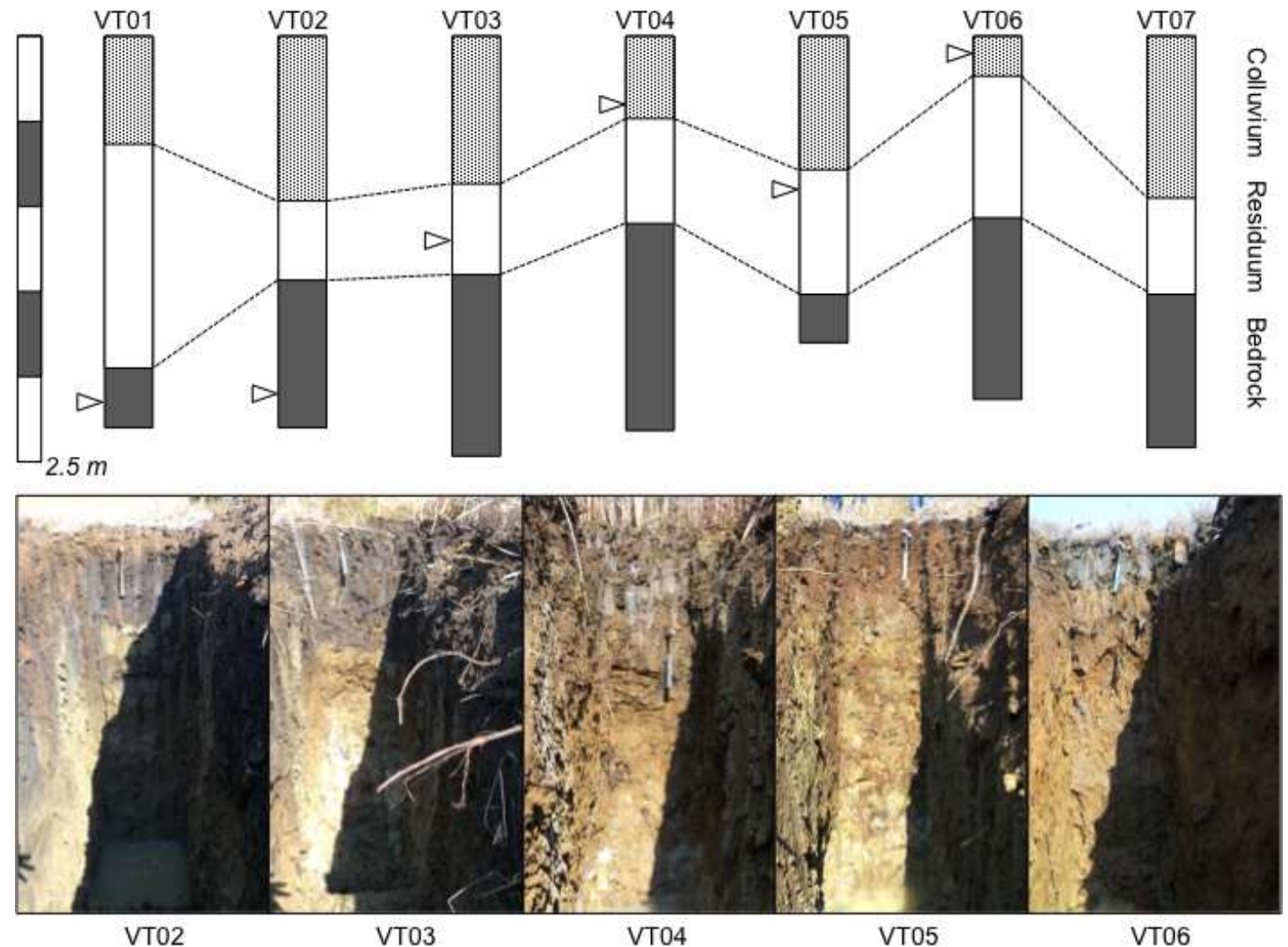

Figure 6. Schematic depiction of soil horizon thickness and depth of water seepage (if any) denoted by triangles, as well as photographs of selected profiles prior to significant water influx. 
VT01, VT02, VT05 and VT07 show a thin open-structured and granular sandy topsoil whereas VT03, VT04 and VT06, which are situated closer to the wetland area, have more cohesive and plastic clayey topsoils. Below this sandy colluvium, all profiles show a similar succession of varying thicknesses of dark brown to black clayey alluvial and colluvial soils grading into orange brown clayey residual sandstone and silstone. Weathered bedrock generally occurs at depths greater than $1.50 \mathrm{~m}$.

The topsoil variations are expected to be a function of transport and pedogenetic processes. Colluvium is generally more sandy and more porous with material originating from upslope, whereas alluvium transports fine clayey sediments to be deposited along the wetland. Lateral and vertical leaching of clays result in the distinctive duplex soils forming along the brim of the wetland.

\subsection{Hydrological characterisation}

Water seepage was encountered in all test pits with the notable exception of VT07. Although situated adjacent to the waterlogged area, interflow appears to be accentuated to the east of the wetland and possibly excluding the western side. A throughflow system is likely, or alternatively the position where VT07 was excavated may be more likely to serve as a highly evaporative zone (as is evident by the surface precipitation of salts). A third possibility is the likelihood that VT07 would eventually have shown seepage but that subsurface permeability is too slow for rapid water influx. 


\subsection{Geotechnical characterisation}

Excavation is soft to depths exceeding grave depth $(1.80 \mathrm{~m})$ and all sidewalls are stable. However, water seepage and the occurrence of excessively clayey horizons highlight the likelihood of water influx into graves. Backfilling of graves with in-situ material may result in poor permeability and difficulty in compaction of highly cohesive soils, notably during drier seasons when the clays may be stiff and possibly dessicated. The likelihood of selective backfilling, i.e. using only the granular fractions due to better workability, may furthermore create preferential pathways for water from surface.

\subsection{Conceptual model}

A cross-section was constructed based on detailed soil profile descriptions and transects the wetland along VT07-VT04-VT01 (Fig. 7). Water originates from upslope (in the vicinity of VT06) and collects in the wetland system from where interflow appears to predominate towards the southeast. In this instance, the system is considered a losing stream not in direct contact with the phreatic surface (which is expected to be well below $10 \mathrm{~m}$ depth, based on the afforementioned map series). Additionally, the system appears to behave as a throughflow system with water sourced from upslope and moving through the wetland rather than out of it in all directions. 


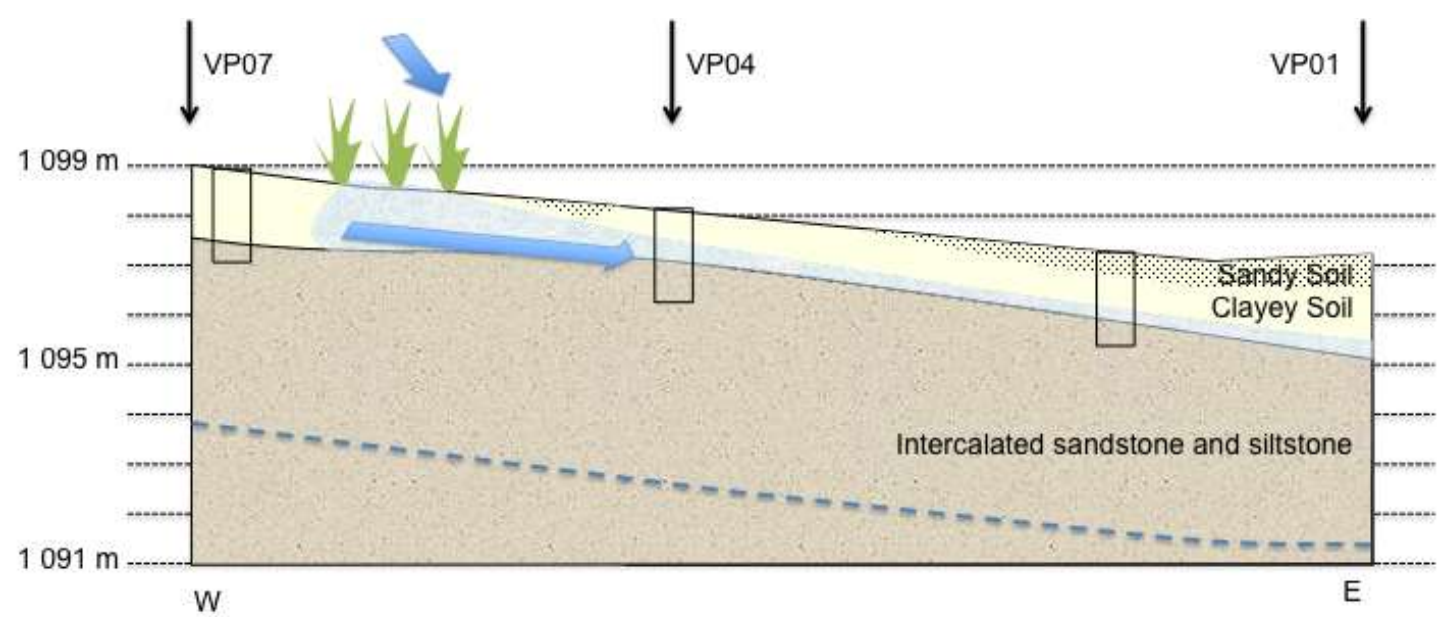

Figure 7. Conceptual model depicting flow through the wetland obliquely through the streamflow direction (200 m across); note a regional groundwater table is inferred and local variations or multiple water tables may exist.

The distinct presence of duplex soils followed by evaporation/ precipitation zones towards the wetland insinuates unsaturated interflow resulting in intermittently or seasonally waterlogged conditions between the wetland and the duplex soils. This water may represent yet a shallower perched water table moving within or just below the soil zone, which may or may not be in distinct contact with the deeper perched water table occuring on the bedrock head (Fig. 7). This scenario may be driven either from upslope as detailed above, or may alternatively be associated with the same losing stream system through which the wetland feeds this evaporative zone with the duplex soil forming as the moisture is lost to the atmosphere and clays become immobile. 


\section{Conclusions}

\subsection{Provisional findings and way forward}

Basic geological characterisation techniques have been employed to conceptualise the hydrological interaction at a cemetery site developed near a seasonally waterlogged wetland. The phreatic surface is deep (in excess of $10 \mathrm{~m}$ ) and subsequently the seepage detected in the trial holes are not in direct contact with the regional groundwater table.

Slopes terminate in duplex soils (plastic clayey topsoil) followed by evaporation/ precipitation zones (porous, open-structured sandy topsoil) and finally the wetland. The upper slopes are generally drier to greater depth with water being on surface in the wetland and at shallow depth in the evaporation/ precipitation and duplex soil zones to the east of the wetland. The distinct absence of seepage in the only western profile may suggest throughflow, although confirmation through additional profiling to the west is required for definitive clarification.

Fine-grained site soils induce surface ponding and very slow infiltration, which can enhance the waterlogged status of the site during wet seasons, which may be exacerbated when using this same material as backfill. More recent processes resulting from this primary low permeability are evident through clay translocation and evaporation. 
A losing stream system is suggested whereby the wetland is fed from the upper reaches of the small catchment and water enters the proximate vadose zone from the wetland. The implications are important as this suggests that interflow water may not flow towards the wetland and subsequently that surface water is likely protected against possible contamination. The same does not necessary hold for groundwater and the thickness and properties of the vadose zone will govern this.

Even in dry months, the excavation and proper interpretation of soil profiles would have highlighted the likelihood of shallow seepage into grave pits. Although the proximity of the wetland should be a clear indicator, such processes are common in South Africa without any real connection to surface drainage features. Low precipitation and high evapotranspiration commonly result in perched water table systems and limited intrusive investigation is key in identifying such scenarios.

Excavation to the west of the wetland and water quality comparison for the wetland, seep water and groundwater are underway. This will aid in validating the conceptual model and in addressing possible existing contamination of water at the site.

\subsection{Provisional guidelines}

The final phased of the project entails guidelines for investigations for cemetery sites. Provisionally, a two-fold system is proposed. The first is a Cost-Effort-Risk 
Screen to rank appropriate investigation techniques to the anticipated risk, and the second a standard multi-faceted Vadose Zone Assessment Protocol.

The Cost-Effort-Risk Screen evaluates existing methods in comparison to the anticipated costs and effort in acquiring data. Rankings A to E can be correlated to tiered approaches, phases of investigation or the requirement for increased data accuracy at higher risk sites. A suggested outline is as follows:

A. Negligible Risk Investigations and Preliminary Investigations; very few to no possible receptors, very deep groundwater and no distinct proximate surface drainage features.

B. Low Risk Investigations and Land Use Planning Stage; very low risk areas; very low density or very small size cemeteries; no proximate groundwater or surface water users or bodies; deep groundwater ( $>20$ $\mathrm{m})$

C. Moderate Risk Investigations and Design Stage; low density or small size cemeteries; some groundwater or surface water users or bodies within $500 \mathrm{~m}$; groundwater $>10 \mathrm{~m}$; possible influence on water bodies and users

D. High Risk Investigations and Construction Stage; high density or large cemeteries, small land fills, water treatment works etc.; probable influence on water bodies and users

E. Very High Risk Investigations and Detailed Modelling; very large cemeteries, land fills, water treatment works etc.; definitive influence on water bodies and users. 


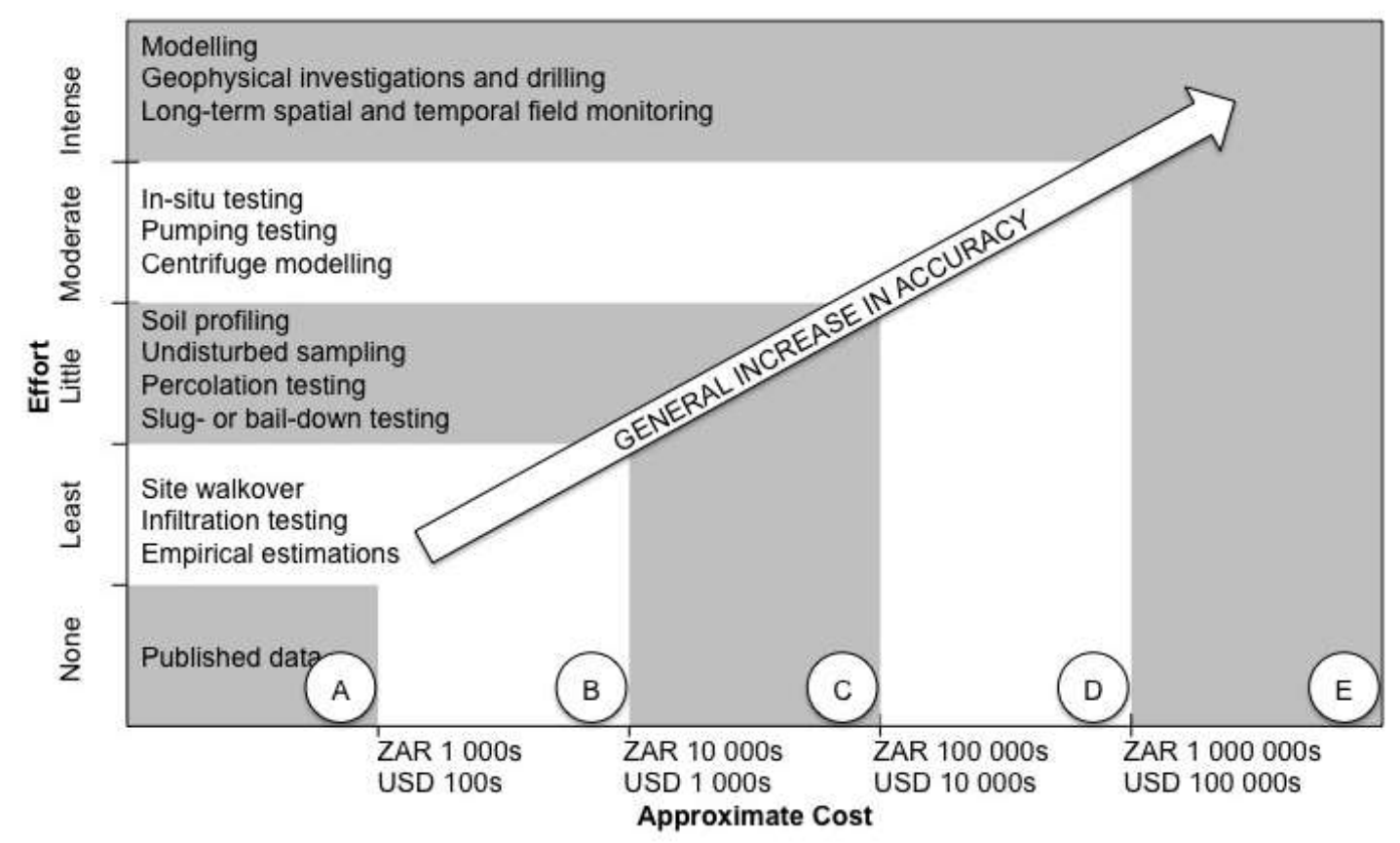

Figure 8. Cost-Effort-Risk Screen to evaluate available methods of investigation for fixed budgets (in South African Rands, ZAR, and approximate equivalent US Dollar, USD) and effort.

The multi-faceted Vadose Zone Assessment Protocol aims to incorporate strengths of a range of separate disciplines in proper characterisation of the complete vadose zone (including, for instance, the fractured vadose zone and secondary porosity, both of which are not clearly addressed in existing guidelines). This correlates to the addressed existing approaches, which are based on geotechnical and sanitary aspects, but with more distinct specification and for use in any vadose zone assessment and not solely cemeteries. In terms of this approach, the recommended process is ranked in sequence of Cost-Effort Risk Screen and should be populated where concerns arise from the preceding step:

A1. Data Collation (geological and soil maps; climatic data; existing water quality data; historical reports)

A2. Assessment of Proposed Development and Associated Risks) 
A3. Hydrological Pathways of Importance (i.e. is water required to be available to plants; is groundwater recharge and aquifer vulnerability the main concern; is water expected to influence infrastructure?)

B1. Detailed Surface Mapping (outcropping rock, surface soils, land cover, land use, vegetation, drainage, topography)

B2. Relative Hydrological Risk Mapping (contaminant sources, water table map, water users, surface drainage)

C1. Surface Water Assessment (detailed drainage; surface water quality)

C2. Soil Zone Assessment (characterisation of the shallow subsurface through existing methods such as soil profiling, infiltration testing, percolation testing, grading and hydrometer analyses, etc.)

C3. Geotechnical Assessment (excavatability; sidewall stability; geological hazards)

D1. Phreatic Zone Assessment (hydrocensus; drilling and aquifer testing if required; groundwater quality)

D2. Intermediate Vadose Zone Assessment (conceptualisation of deep soil and unsaturated bedrock conditions; drilling, augering or push probe if required)

E1. Hydrological Model (including all additional data requirements).

Following such a hierarchical approach will ensure detection of possible problems prior to extensive efforts and costs and will also direct future investigation towards the most likely issues. For cemetery sites, all stages are recommended although D2 and E1 can be solely at conceptual level. In the event 
that the site is waterlogged or adjacent to seasonal or intermittent water bodies, cemetery development should not proceed.

These guidelines are presently being validated and formalised and will be collated into a formal document dictating minimum requirements and standardised methods.

\section{Acknowledgements}

The author wishes to acknowledge the South African Water Research Commission (WRC) of South Africa for funding of project K5/2052 on Multidisciplinary Vadose Zone Hydrology. Additional acknowledgement is extended to all parties involved in the project for help with data collection and for discussion about the topic, as well as the valuable input from the anonymous reviewers.

\section{Bibliography}

1. Brink, A. B. A. (1983). Engineering Geology of Southern Africa. Volume 3: The Karoo Supergroup. Building Publications. Pretoria. -320pp.

2. Croucamp, L., \& Richards, N. (2002). Guidelines for Cemetery Site Selection. Council for Geoscience. Pretoria.

3. DEAT [Department of Environmental Affairs and Tourism]. (1989). Environmental Conservation Act No 73. Government Printer. Pretoria. 
4. Dent, B. B. and Knight, M. J. (1998). Cemeteries: a Special Kind of Landfill. The Context of their Sustainable Management.. Proceedings: Groundwater: Sustainable Solutions (International Association of Hydrogeologists, Melbourne, February 1998):451-456.

5. DWA [Department of Water Affairs]. (1998). National Water Act No 36. Government Printer. Pretoria.

6. DWA [Department of Water Affairs]. (Retrieved 2010). Water Quality Management Policy with regard to the Management of and Control over Cemeteries as a Source of Water Pollution. Document number: GraveR. Available on the Internet at http://www.dwaf.gov.za/Documents/Policies/WDD/Cemetery.pdf. 2 pages.

7. EA [Environmental Agency]: Science Group Air, Land \& Water. (2004). Assessing the Groundwater Pollution Potential of Cemetery Developments. Product Code SCH00404BGLA-E-P. Environmental Agency. Bristol. 24 pages.

8. Engelbrecht, J. (2000). Goundwater Pollution for Cemeteries. CSIR. Pretoria.

9. Fisher, G. (1992). Selection Criteria for the Placing of Cemetery Sites. Geological Survey of South Africa. Johannesburg.

10. Fisher, G. J. (1994). The Selection of Cemetery Sites in South Africa. Proceedings: 4th Terrain Evaluation and Data Storage Symposium. Midrand.

11. Fisher, G., \& Croucamp, L. (1993). Groundwater Contamination and its Consequences resulting from the Indiscriminate Placing of Cemeteries in 
Third World Context. Vol 1: Africa needs Groundwater Convention. (Vol. 1). Johannesburg.

12. Hall, B. H. and Hanbury, R. (1990). Some Geotechnical Considerations in the Selection of Cemetery Sites. IMIESA March 1990: 2125

13. Johnson, M. R., Van Vuuren, C. J., Visser, J. N. J. Cole, D. I., Wickens, H. de V., Christie, A. D. M., Roberts, D. L. and Brandl, G. (2009). Sedimentary Rocks of the Karoo Supergroup. In: Johnson, M. R., Anhaeusser, C. R. and Thomas, R. J. (Eds.) The Geology of South Africa. Geological Society of South Africa, Johannesburg/ Council for Geoscience, Pretoria. 461-500.

14. NIEA [Northern Ireland Environment Agency]. (downloaded 2012). Cemeteries, Burials \& the Water Environment: Guidance Notes. Available on the Internet at www.ni-environment.gov.uk. 12 pages.

15. WHO [World Health Organisation]: Regional Office for Europe. (1996). The Impact of Cemeteries on the Environment and Public Health: an Introductory Briefing. Document EUR/HFA target 23. World Health Organisation. Copenhagen.

16. Young, C. P., Blackmore, K. M., Reynolds, P. and Leavens, A. (2002). Pollution Potential of Cemeteries: Draft Guidance. R\&D Technical Report P223. Environmental Agency. Bristol. 71 pages. 